\title{
Financial Convergence or Decoupling in Electricity and Energy Markets? A Dynamic Study of OECD, Latin America and Asian Countries
}

\author{
John Simpson ${ }^{1} \&$ Santosh Mon Abraham ${ }^{1}$ \\ ${ }^{1}$ School of Economics and Finance, Curtin University, Australia \\ Correspondence: John Simpson, School of Economics and Finance, Curtin University, Australia. E-mail: \\ simpsonj@cbs.curtin.edu.au
}

Received: September 10, 2012

Accepted: October 19, $2012 \quad$ Online Published: October 23, 2012

doi:10.5539/ijef.v4n12p1

URL: http://dx.doi.org/10.5539/ijef.v4n12p1

\begin{abstract}
The motivation for this theoretical paper is to "shed further light" on electricity market liberalisation. The major influences on electricity prices in each country are local supply and demand conditions, which include costs of renewables and/or regulatory effects on pricing. This also includes effects of public or private monopoly pricing. However, many countries from a representative sample of groups of economies, show long-term equilibrium relationships in their electricity and energy stock market sectors. In these countries in the short-term, exogeneity lies with the energy sectors in the EMU, the UK, New Zealand, the Philippines, Hong Kong and Thailand. In the cases of the US and India the electricity markets are exogenous, which is probably due to the sheer size of those markets. Where there is evidence of cointegration the nexus between electricity and energy sectors remains and the strength of this relationship is indicative of greater progress in electricity market liberalisation. This is because their electricity prices are influenced to a significant degree by global fossil fuel supply costs. In those cases domestic factors such as cost of regulatory environments are less important.
\end{abstract}

Keywords: energy sector, electricity, VECM, VAR, Granger, causality, pricing, regulatory environment, country, fossil fuels

JEL: C22, C52, O13, Q43

\section{Introduction}

The central point of this study is that those electricity markets, whose costings largely depend on global fossil fuel prices, possess a greater degree of deregulation than those markets that do not have such a high reliance on world energy prices. That is, these markets are less reliant on government intervention or private or public monopoly pricing. This study differs from previous studies as it utilises energy stock market data to represent global fossil fuel prices. The study also examines a greater range of country electricity markets in a dynamic analytical framework.

The paper is motivated by a need for a straightforward analytical method to broadly explain the progress and extent of country electricity market deregulation. The study expands a contemporaneous study in an auto regressive conditional heteroskedasticity (ARCH) model by Simpson, Buyukkara and Mon Abraham (2012). Similar relationships are herewith examined in a vector error correction (VECM) model in order to ascertain if optimally lagged models provide a better fit and assist in providing a better explanation of the forces behind electricity market deregulation. The study therefore relaxes the assumption of contemporaneous adjustment of energy and electricity markets.

The sample of countries is representative of economic groups for the OECD, Latin America and Asia. The strongest significant relationships in their unlagged models over two sub-periods of differing fossil fuel price volatility were the EMU, China, the US, India, Chile, UK, Brazil, Canada, Hong Kong, Thailand, Malaysia, Argentina and New Zealand in that order. The assumption of contemporaneous movement in prices in each market in the Simpson, et al., (2012) paper is deemed too strict, so this paper takes the model into an optimally lagged VECM and runs VECM based cointegration and exogeneity tests.

There is a continuing need to monitor convergence or otherwise of various country electricity markets with country energy sector markets. There are policy implications relating to the degree of progress of electricity market deregulation and liberalisation in various countries, country economic groups and regions. The concept 
of electricity liberalisation is based on the premise that, historically, electricity supply has been a natural monopoly and, as such, it has required costly regulation to enforce competition. The British model is the standard in OECD countries. This model began in the late 1980s with the privatisation and de-integration of the electricity industry where a system of competition was established to auction spare capacity through a central system. Anecdotally, such a system benefits large industrial consumers, but the benefits to domestic consumers are questionable when electricity supply through a public monopoly is compared to that through a regulated private monopoly. Whichever the case monopoly pricing through market power is expected to apply to inflate electricity prices.

In this study, the starting point is to consider energy stock market sectors. It is first recognised that prices in domestic energy stock market sectors are dominated by energy costs in global energy supply from fossil fuels. Country energy sector prices thus depend to a large extent on global energy market prices, because country energy sectors represent companies involved in production and distribution of fossil fuels and fossil fuels have a global price. Prices in country electricity markets depend on both supply cost factors (based on global energy prices) interacting with local demand and pricing factors. The latter are in a large part affected by the degree of government intervention in relation to government ownership, deregulation, competition and privatisation in the various electricity industry processes of generation, transmission and distribution. A literature review from a search of energy economics publications reveals a recent increase in studies that examine the relationships between electricity prices and fossil fuel prices. Most evidence finds a relationship (either contemporaneous or lagged) but, the strength of those relationships varies in different countries.

For example, Bosco, et al., (2006) finds a commonality of trend among European electricity prices and a long-term equilibrium relationship of this trend with oil prices. Asche, et al., (2006) in a UK study finds cointegration between natural gas, crude oil and electricity prices with a leading indicator role of crude oil. Other country studies show variations in the strength of relationships and causality between fossil fuel prices and electricity. For example, Mjelde and Bessler (2009) and Mohammadi (2009), utilised lagged times series models to explore integration, long-run equilibrium relationships and exogeneity between electricity prices and fossil fuels; a Chinese study by He, et al., (2010) examined coal prices and electricity markets; a Spanish electricity study by Mautinho, et al., (2011) found important relationships with energy commodity prices.

Ferkingstad, et al., (2011) studied Nordic, German and UK electricity prices in contemporaneous and lagged time series models with oil, coal, gas, wind and water reservoir levels and find a link of electricity with gas. The UK electricity and British gas and electricity prices were found to adjust by themselves as fossil fuels and the Euro/USD exchange rate were weakly exogenous. Furio and Chulia (2012) find cointegration between Brent oil crude forwards, Zeebrugge gas forwards and Spanish electricity forwards with causality running from the fossil fuels to the electricity market.

In relation to the analysis, the connection between energy stock market sectors in each country and fossil fuel supply costs (as components of electricity pricing) must first be examined bearing in mind the mixed findings of past cointegration studies on fossil fuel prices only. Oil remains the most important global source of energy and the prices of other fossil fuels show some correlation. The essential contribution to the literature in this paper is the specified model's demonstration of the use of energy stock market sector prices, in lieu of global fossil fuel prices, to explain the extent of electricity market deregulation in various markets.

Figure 1 demonstrates an implied important relationship between world oil prices (OPEC) and the global energy stock market sector. It is thus implicit that the prices of fossil fuels are correlated as energy stock market sectors reflect global fossil fuel prices. 

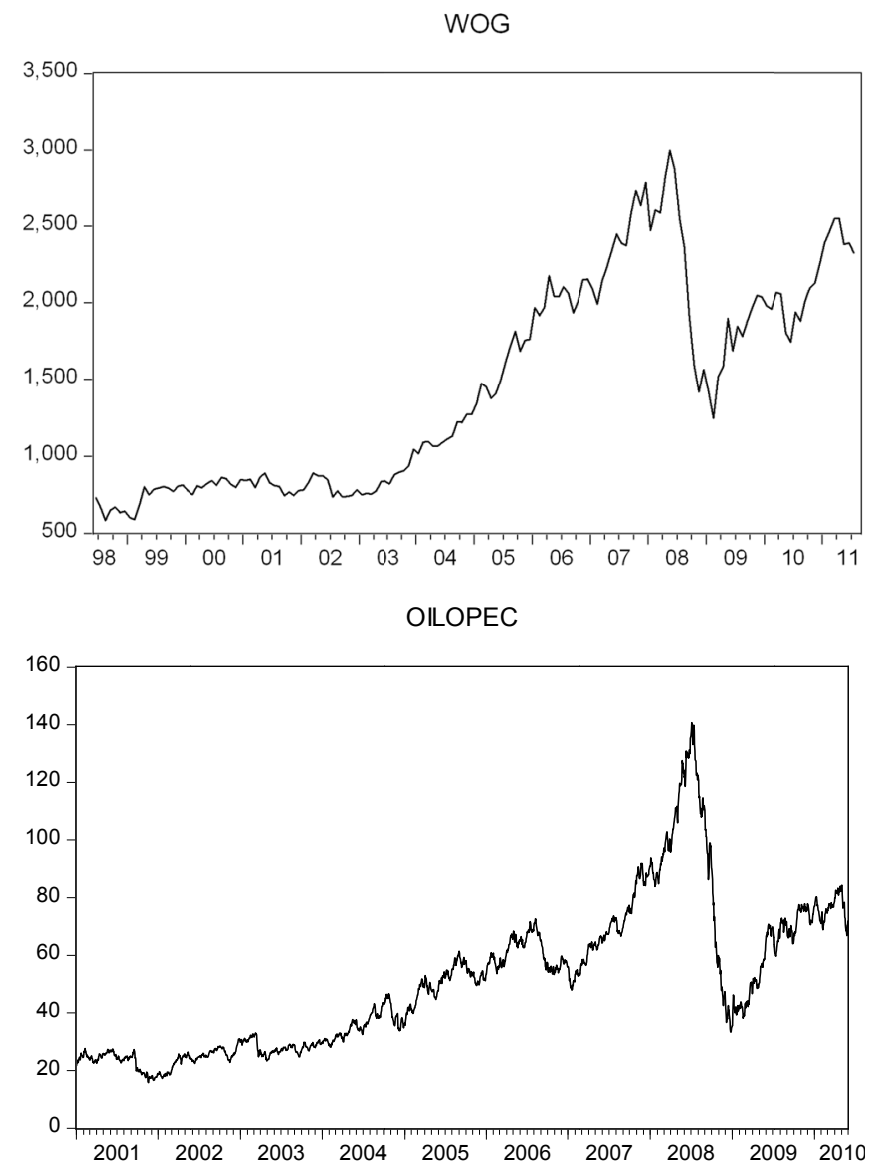

Figure 1. The relationship between the global stock market energy sector and global oil prices

Note: WOG is the world stock market energy sector price index based on US dollars. OILOPEC is the OPEC oil price in US dollars per barrel. Data sourced from DataStream.

Figure 2 tracks the powerful US energy stock market sector as another example of how energy sectors in domestic stock markets relate to the global energy market.

USOG

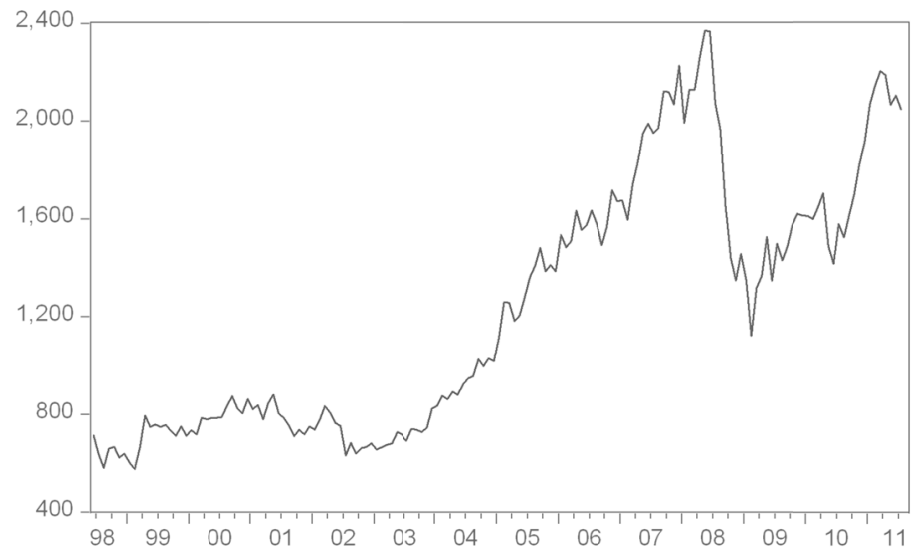

Figure 2. US stock market energy sector prices

Note: This graph needs to be compared to those in Figure 1. USOG is the US stock market energy sector price index based on US dollars. Data is sourced from DataStream. 
Figures 1 and 2 demonstrate implicitly that country energy stock market sectors are strongly related to global energy prices. However, the central question is whether or not strong relationships exist between country electricity and energy stock market sector prices.

The issues for the study are as follows:

1. Do sampled country electricity prices and their energy sector prices possess long-term equilibrium relationships?

2. If evidence is produced of cointegration does short-term exogeneity run from the country energy sectors to the electricity sectors?

The answers to these questions will lead to conclusions in relation to electricity market and energy sector decoupling (regulation) or convergence (deregulation/liberalisation) in different countries representative of country economic groups. It will provide a basic indicator model of the degree of electricity market liberalisation in the various countries investigated.

\subsection{Electricity Regulatory Environments and Energy Commodity Supply}

In all electricity markets studied, there are varying degrees of government intervention that affect domestic electricity supply and demand and therefore pricing. There are also varying degrees of internal renewables energy supply that affect electricity supply costs bearing in mind that energy stock market sectors reflect global supply prices of fossil fuels. Much of the following country examples of factual and background information on electricity markets is provided in the Simpson, et al., (2012) study.

For example, in the US the reliance on fossil fuels in mainly coal and gas for power generation is well documented. The electricity sector includes a large number and array of stakeholders providing generation, transmission and distribution services to industrial and domestic consumers across the country. The market segments are regulated by different public institutions with some functional overlaps. The US government sets general policy through the Department of Energy but there are other public institutions that set policy for example in environmental impact and consumer protection. Economic regulation in distribution is a state government responsibility. The US is a very large electricity market and economy and the regulatory environment is favourable with electricity pricing less likely to be interfered with by government. It remains likely that US electricity prices will continue to show a stronger relationship with energy sector prices than many other countries. In addition, the regulatory environment has promoted competition and fairer pricing than in many other countries.

The New Zealand electricity power transmission national grid is owned by the State owned enterprise, Transpower New Zealand Ltd. Seventy percent of energy supply is provided internally by renewables (hydropower, geothermal and wind) and while this makes New Zealand a low carbon dioxide emitter it is not a highly energy efficient country when comparing economic output to consumption. There is likely to be a weaker long-term relationship in New Zealand electricity markets with their energy sector because of greater regulation and reliance on domestic supplies of renewables.

The electricity market in the EMU is mainly influenced by legislation passed in the European Union where electricity market liberalisation and security of supply has been promoted, for example, through the 2003 International Market in Electricity Directive. The European Union has also legislated in energy policy when, for example, in October 2005 the European Council approved a comprehensive energy policy taking into account the fact that Europe is currently the largest importer of fossil fuels (oil and gas) in the world. Most energy supply is from fossil fuels. Uranium supplies nuclear power generation to a lesser extent, but the Europeans are committed by a council directive on Electricity Production from Renewable Energy Sources in 2001, which stated that $22 \%$ of European energy requirements from renewables needed to be in place by 2010 . Europe is a very large electricity market. It is expected that due to a continued reliance on fossil fuels and substantial progress in electricity market liberalisation, electricity prices in the EMU will be reflected in a stronger relationship with energy stock market prices.

The Argentina electricity market price is expected to possess a lower relationship with the energy sector price because fifty four percent of energy sources are internally generated in thermal systems and forty one percent are also internally supply from hydropower. Whilst the electricity market is one of the most deregulated and competitive in Latin America the government agency, the Energy Secretariat has the power of veto over CAMMESA (the administrator of the wholesale market) and can alter the functioning of the market in electricity generation, transmission and distribution. The Argentina electricity market is small compared to that in the EMU, China, and the United States. In addition the effect of the potential for government interference (through the 
Energy Secretariat) on electricity demand and pricing is likely to be of greater importance in terms of explanatory power of electricity pricing over all periods of the study.

In 1996 China's Electric Power Law was implemented in order to develop the electricity industry and protect consumers and investors. It aimed to regulate the generation, distribution and consumption of electricity. In 2002 the State Power Corporations monopoly was dismantled and 11 smaller corporations were established. The State Power Corporation had previously owned $46 \%$ of electricity generation and $90 \%$ of electricity of supply assets. Ongoing reforms are dealing with the separation of power plants from power supply networks, privatisation of a significant amount of stated owned property, the encouragement of competition and the revamping of pricing mechanisms. In relation to energy supply, $78 \%$ of power is generated from coal fired plants and around $15 \%$ is hydropower. China is a very large electricity market and economy but is still developing in terms of macro and micro economic reforms. It is still likely that there exists, in lagged data, a weaker relationship between electricity and energy sectors.

Due to a strong surge in demand for electricity, the Malaysian government divested Tenaga Nasional (the owner of the national grid) in 1992 and awarded independent power producers (IPPs) licences to build plant and sell electricity to Tenaga for transmission and distribution. The licences were awarded without tender quite possibly to friends of the government and large profits were made at Tenaga's expense. Malaysia's electricity market is also small compared to those in, for example, the EMU, China and the United States. Whilst fossil fuels dominate renewables, such as hydropower in energy supply, the relationship between electricity prices and the energy market sector prices is expected to be lower over all periods of the study due to the probability of instances of corruption and government indirect interference in electricity pricing.

\section{Method}

The data in daily electricity prices and energy stock market indices for each country are compared in bivariate lagged models over a period from 31/12/1999 to 30/12/2011. The countries selected for investigation were those that have both electricity and energy market sector prices simultaneously reported over the period of the study. Data for electricity prices are extracted from Bloomberg's and that for energy stock market sectors from DataStream.

Electricity prices in each country reflect the prices paid by domestic and industrial users. Energy sector indices represent listed companies in each country in the businesses of production and distribution of energy in the predominant forms of oil, gas and coal. To partially control for differences between measurements of prices in different countries, the data are standardised in a logarithmic format. Structural break tests provided by Quandt (1988) and Andrews (1993) reveal a break at the beginning of the global financial crisis, but testing the model over two periods in unlagged data does not reveal enough evidence to suggest that the basic conclusions of the study should alter between the period up to the break, after the break and over the full period. The full period is therefore studied without any loss of degrees of freedom and it thus includes the rapid fall in energy prices during the global financial crisis from 2008. The countries selected for investigation are those that have both electricity and energy market sector prices simultaneously reported over the period of the study.

Taking the contemporaneous model in Simpson, et al., (2012) further, an optimally lagged bivariate vector autoregressive (VAR) model is initially specified in logarithmic level series prices.

$$
E l_{i_{t}}=\alpha_{i_{t}}+\beta\left(E L_{i_{t-n}}\right)+\beta(E M)_{i_{t}}+\beta\left(E M_{i_{t-n}}\right)+e_{i_{t}}
$$

Where;

$E L_{i_{t}}$ is the electricity price in country $i$ at time $t$.

$E M_{i_{t}}$ is the energy sector index in country $i$ at time $t$. This variable represents global factors such as global energy prices impacting country energy market prices as a determinant of country electricity prices.

$\alpha_{i_{t}}$ is the regression intercept reflecting current commencement or base electricity market prices and electricity market conditions for country $i$ at time $t$.

$e_{i_{t}}$ is the residual of the regression for country $i$ at time $t$ representing the contribution to the variance of country electricity prices from factors other than energy sector price changes in country $i$ and this includes the domestic effect on prices of renewables costings and government regulation and control of the country electricity market.

$n$ denotes the optimal lag determined by lag exclusion tests and information criteria. 


\section{Results}

Unit root tests were run in Phillips Perron (PP), the latter deemed reliable, based on the evidence of structural breaks (Phillips \& Perron, 1988). The PP test results are reported in Tables 1 and 2.

Table 1. Unit root tests: Electricity prices

\begin{tabular}{lll}
\hline Country electricity price & Test statistic: Level series & Test statistic: First differences \\
\hline US & -1.7586 & $-59.2435^{*}$ \\
United Kingdom & -0.7525 & $-58.6750^{*}$ \\
New Zealand & -1.8735 & $-53.5843^{*}$ \\
Canada & -1.8067 & $-54.3825^{*}$ \\
EMU & -1.0163 & $-53.887^{*}$ \\
Argentina & -1.6808 & $-46.9602^{*}$ \\
Brazil & -1.0863 & $-54.3337^{*}$ \\
Chile & -0.4004 & $-48.3921^{*}$ \\
Malaysia & -2.2750 & $-56.7631^{*}$ \\
Thailand & -1.1845 & $-58.7354^{*}$ \\
India & -1.3012 & $-52.8482^{*}$ \\
Hong Kong & -0.6891 & $-63.7173^{*}$ \\
China & -1.8911 & $-54.3082^{*}$ \\
The Philippines & -0.4305 & $-49.8534^{*}$ \\
\hline
\end{tabular}

Note: Critical values for PP test are -3.4326 at the $1 \%$ level; -2.8623 at the $5 \%$ level and -2.5672 at the $10 \%$ level. Level series test statistics are not significant at the $1 \%$ level. First difference test statistics are all significant at the $1 \%$ level and denoted *

Table 2. Unit root tests: Energy sector prices and errors of the electricity price regression

\begin{tabular}{llll}
\hline Country & Energy sector in levels & Energy sector in first differences & $\begin{array}{l}\text { Errors of electricity/energy } \\
\text { sector regression in first } \\
\text { differences }\end{array}$ \\
\hline US & & & $-267.4487^{*}$ \\
United Kingdom & -1.0485 & $-61.2221^{*}$ & $-267.4487^{*}$ \\
New Zealand & -2.3907 & $-57.5774^{*}$ & $-232.6754^{*}$ \\
Canada & -1.7344 & $-52.1353^{*}$ & $-203.7645^{*}$ \\
EMU & -1.7154 & $-55.3268^{*}$ & $-166.6072^{*}$ \\
Argentina & -1.8629 & $-56.5766^{*}$ & $-143.0318^{*}$ \\
Brazil & -1.4431 & $-52.5680^{*}$ & $-257.3371^{*}$ \\
Chile & -1.6123 & $-53.1784^{*}$ & $-167.5751^{*}$ \\
Malaysia & -0.0216 & $-49.2856^{*}$ & $-293.3868^{*}$ \\
Thailand & -1.0323 & $-55.8923^{*}$ & $-228.8398^{*}$ \\
India & -1.0302 & $-55.8577^{*}$ & $-188.7806^{*}$ \\
Hong Kong & -0.5885 & $-50.3945^{*}$ & $-152.6845^{*}$ \\
China & -1.6096 & $-55.1666^{*}$ & $-185.5977^{*}$ \\
The Philippines & -0.6103 & $-56.8573^{*}$ & $-353.9744^{*}$ \\
\hline
\end{tabular}

Note: Critical values for PP test are -3.4326 at the $1 \%$ level; -2.8623 at the $5 \%$ level and -2.5672 at the $10 \%$ level. Level series test statistics are not significant at the $1 \%$ level. First difference test statistics are all significant at the $1 \%$ level and denoted *

The level series are non-stationary in each case and the first differences are stationary, including the errors of the various relationships. In each case it was evident that the variables were integrated non-stationary processes and the analysis moved to VAR analysis, in order to discover the appropriate lag order and to run initial cointegration tests after testing the VAR model for stability. When cointegration is discovered in a country VAR, it is, with the discovered lag order, respecified into a VECM and the variables re-tested for cointegration (Johansen, 1988).

If cointegration is re-discovered in the VECM Granger causality tests (Granger, 1988) and impulse response functions are run for each country concerned. Cointegration and Granger causality results follow for each country economic group and the results of impulse response functions are reported in Appendix 1 for countries that demonstrate cointegration evidence with Granger causality evidence either dual or one-way between 
electricity and energy markets. Tables 3 and 4 show the cointegration and exogeneity test results for the country groups where cointegrating relationships are discovered.

\section{$\underline{\text { OECD }}$}

Table 3. VECM results for cointegration and exogeneity: OECD countries

\begin{tabular}{|c|c|c|c|c|}
\hline Country & Cointegration & $\begin{array}{l}\text { Test } \\
\text { assumptions }\end{array}$ & $\begin{array}{l}\text { Granger causality in price } \\
\text { changes/maximum significant } F \\
\text { statistic }\end{array}$ & $\begin{array}{l}\text { Lag for exogeneity of } \\
\text { price changes }\end{array}$ \\
\hline $\begin{array}{l}\text { United } \\
\text { States }\end{array}$ & $\begin{array}{l}\text { At least } 1 \text { equation according to } \\
\text { Trace and Maximum Eigenvalue } \\
\text { statistics. Optimum lag according to } \\
\text { Akaike information criteria is one } \\
\text { day. }\end{array}$ & $\begin{array}{l}\text { Data trend: } \\
\text { Linear } \\
\text { Test type: } \\
\text { Intercept and } \\
\text { trend. }\end{array}$ & $\begin{array}{l}\text { Granger causality runs from US } \\
\text { electricity sector to US energy } \\
\text { sector } / 2.7539^{* *}\end{array}$ & 2 days $* *$ \\
\hline $\begin{array}{l}\text { United } \\
\text { Kingdom }\end{array}$ & $\begin{array}{l}\text { At least } 1 \text { equation according to } \\
\text { Trace and Maximum Eigen value } \\
\text { statistics. Optimum lag according to } \\
\text { Akaike information criteria is } 1 \text { day. }\end{array}$ & $\begin{array}{l}\text { Data trend: None } \\
\text { Test type: No } \\
\text { intercept with no } \\
\text { trend. }\end{array}$ & $\begin{array}{l}\text { Dual causality*** but stronger } \\
\text { causality is from UK electricity } \\
\text { sector to UK energy sector/ } 8.1027^{*}\end{array}$ & 2 days*. \\
\hline $\begin{array}{l}\text { New } \\
\text { Zealand }\end{array}$ & $\begin{array}{l}\text { At least } 1 \text { equation according to } \\
\text { Trace statistics. Optimum lag } \\
\text { according to Akaike information } \\
\text { criteria } 1 \text { day.* }\end{array}$ & $\begin{array}{l}\text { Data trend: None. } \\
\text { Test type: } \\
\text { No intercept with } \\
\text { no trend. }\end{array}$ & $\begin{array}{l}\text { No significant Granger causality } \\
\text { on a one day up to five lags. }\end{array}$ & $\begin{array}{l}\text { No evidence of } \\
\text { Granger causality. . }\end{array}$ \\
\hline Canada & $\begin{array}{l}\text { No cointegration according to Trace } \\
\text { and Maximum Eigen value statistics. }\end{array}$ & $\begin{array}{l}\text { No cointegration. } \\
\text { Not applicable }\end{array}$ & No cointegration. Not applicable & $\begin{array}{l}\text { No cointegration. Not } \\
\text { applicable }\end{array}$ \\
\hline EMU & $\begin{array}{l}\text { At least } 1 \text { equation according to } \\
\text { Trace and Maximum Eigen value } \\
\text { statistics. Optimum lag according to } \\
\text { Akaike information criteria } 1 \text { day.* }\end{array}$ & $\begin{array}{l}\text { Data trend: None. } \\
\text { Test type: } \\
\text { No intercept with } \\
\text { no trend. }\end{array}$ & $\begin{array}{l}\text { No significant evidence of Granger } \\
\text { causality on lags of one up to five } \\
\text { days. }\end{array}$ & $\begin{array}{l}\text { No evidence of } \\
\text { Granger causality. }\end{array}$ \\
\hline
\end{tabular}

Note: For Tables 3 and 4 the cointegration lag order for the VAR/VECM is deduced from information criteria. The assumptions relate to trends and intercepts. Granger causality is taken from pairwise tests of the bivariate models with the lag on log differenced variables based on significant maximum $\mathrm{F}$ statistics. *denotes significance at the $1 \%$ level and $* *$ denotes significance at the $5 \%$ level. $* * *$ denotes significance at the $10 \%$ level.

Cointegration represents evidence that the markets have not decoupled, which in this study represents a degree of market liberalisation, with global fossil fuel prices as the significant drivers of energy stock market sector prices. If the markets are not cointegrated it may be assumed that either market liberalisation is progressing slowly or that governments or public or private monopoly pricing mechanisms are interfering in electricity pricing to a substantial extent or that renewables costs are driving electricity costs. It could be a combination of these factors. In these cases it may be concluded that with greater domestic cost pressures, there is less liberalisation. It is of course possible that if renewables costs are the drivers of electricity prices, market liberalisation could still be progressing with less government regulatory interference.

Table 3 shows that there is at least one cointegrating equation in the interaction of electricity and energy sectors in the OECD sample in the US, the UK, New Zealand and the EMU over the long-term. More-over, in the short-term it is evident that exogeneity runs from the electricity sector to the energy sector in the US and the UK on a 3 and 2 day lag respectively. It is evident that electricity prices are the leading indicators in those countries. Impulse response functions (See Appendix 1), where the electricity price change is delivered a one standard deviation shock, show that in the US and the UK the lag is 3 days and 2 days respectively. After these lags the energy markets in price changes commence their move towards stability, which is achieved in around 6 days and 4 days respectively.

In the US, the EMU and UK major deregulation steps have been taken and the regulatory environment is favourable, with electricity pricing less likely to be interfered with by government or monopoly pricing. It remains likely that the US, the EMU and the UK electricity prices will continue to show a stronger relationship with energy sector prices than many other countries. In addition, the regulatory environments have promoted competition and fairer pricing than in many other countries. Whilst evidence of exogeneity via Granger causality 
tests is not found in the EMU and New Zealand long-term equilibrium relationships exist between electricity and energy sectors thus providing evidence of a degree of liberalisation. The relationships are not as strong in New Zealand. There is no evidence of cointegration in Canadian markets. New Zealand, though a developed country, is a comparatively small electricity market and economy. In terms of the results reported in this paper that there is a weaker relationship between energy market sectors and electricity prices (decoupling) over all periods of the study, first because of the dominance of internal renewables supplies (less influenced by global supply costs of fossil fuels) and second, because of the probable influence of a state owned monopoly on electricity pricing. Whilst there are cointegrating relationships between electricity and energy markets in New Zealand and the EMU there is no evidence of Granger causality in the short-term in those countries and there appears no cointegrating or Granger causal relationships in Canada.

\section{Latin America}

The results of the VECM based tests for the Latin American countries in the sample produce no evidence of significant long-term cointegrating relationships or of short- term exogeneity dynamics. In the cases of these Latin American countries, when lagged data are considered in a VECM, it is evident, by implication, that domestic factors overwhelmingly dominate explanatory power. With the example earlier provided in this paper of Argentina, it is evident in lagged data that decoupling exists between electricity and energy sectors and therefore indicative of a regulated electricity market where electricity prices are driven by both government interference and renewables costings.

\section{$\underline{\text { Asia }}$}

Table 4 shows the results of the VECM cointegration and Granger causality tests for the Asian countries in the sample.

Table 4. VECM results for cointegration and exogeneity: Asian countries

\begin{tabular}{|c|c|c|c|c|}
\hline Country & Cointegration & $\begin{array}{l}\text { Test } \\
\text { assumptions }\end{array}$ & $\begin{array}{l}\text { Granger causality in price } \\
\text { changes/maximum significant } F \\
\text { statistic }\end{array}$ & $\begin{array}{l}\text { Lag for } \\
\text { exogeneity of } \\
\text { price changes }\end{array}$ \\
\hline China & $\begin{array}{l}\text { No cointegration according to Trace and } \\
\text { Maximum Eigenvalue statistics. }\end{array}$ & Not applicable & Not applicable & Not applicable \\
\hline Hong Kong & $\begin{array}{l}\text { At least } 1 \text { equation according to Trace } \\
\text { and Maximum Eigen value statistics. } \\
\text { Optimum lag according to Akaike } \\
\text { information criteria is } 2 \text { days. }\end{array}$ & $\begin{array}{l}\text { Data trend: } \\
\text { Linear } \\
\text { Test type: } \\
\text { Intercept with } \\
\text { trend. }\end{array}$ & $\begin{array}{l}\text { Energy sector drives electricity } \\
\text { sector in price changes } / 31.1380 * *\end{array}$ & 2 days* \\
\hline India & $\begin{array}{l}\text { At least } 1 \text { equation according to Trace } \\
\text { and maximum Eigenvalue statistics } \\
\text { Optimum lag according to Akaike } \\
\text { information criteria } 1 \text { day.* }\end{array}$ & $\begin{array}{l}\text { Data trend: } \\
\text { None. } \\
\text { Test type: } \\
\text { No intercept } \\
\text { with no trend. }\end{array}$ & $\begin{array}{l}\text { No significant Granger causality } \\
\text { on a one day up to three day lags. }\end{array}$ & $\begin{array}{l}\text { No significant } \\
\text { Granger causality. } \\
\text { Not applicable }\end{array}$ \\
\hline Malaysia & $\begin{array}{l}\text { No cointegration according to Trace and } \\
\text { Maximum Eigen value statistics. }\end{array}$ & Not applicable & Not applicable & Not applicable \\
\hline $\begin{array}{l}\text { The } \\
\text { Philippines }\end{array}$ & $\begin{array}{l}\text { At least } 1 \text { equation according to Trace } \\
\text { and Maximum Eigen value statistics. } \\
\text { Optimum lag according to Akaike } \\
\text { information criteria } 1 \text { day.* }\end{array}$ & $\begin{array}{l}\text { Data trend: } \\
\text { Linear } \\
\text { Test type: } \\
\text { Intercept with } \\
\text { trend. }\end{array}$ & $\begin{array}{l}\text { Granger causality flows from the } \\
\text { electricity market to the energy } \\
\text { market on a } 1 \text { day lag***/3.1052 }\end{array}$ & 1 day***. \\
\hline Thailand & $\begin{array}{l}\text { At least } 1 \text { equation according to Trace } \\
\text { and Maximum Eigen value statistics. } \\
\text { Optimum lag according to Akaike } \\
\text { information criteria } 1 \text { day.* }\end{array}$ & $\begin{array}{l}\text { Data trend: } \\
\text { None } \\
\text { Test type: } \\
\text { No intercept } \\
\text { with no trend. }\end{array}$ & $\begin{array}{l}\text { Granger causality runs from the } \\
\text { energy sector to the electricity } \\
\text { sector on a } 1 \text { day lag } / 6.5727^{*}\end{array}$ & 1 day*. \\
\hline
\end{tabular}

Note: For Tables 3 and 4 the cointegration lag order for the VAR/VECM is deduced from information criteria. The assumptions relate to trends and intercepts. Granger causality is taken from pairwise tests of the bivariate models with the lag on log differenced variables based on significant maximum $\mathrm{F}$ statistics. *denotes significance at the $1 \%$ level and $* *$ denotes significance at the $5 \%$ level. $* * *$ denotes significance at the $10 \%$ level. 
Cointegration evidence is found in Hong Kong, India, the Philippines and Thailand. This indicates progress in liberalisation in those markets when lagged data are considered. No evidence of Granger causality is discovered in India, however causality runs from the energy sector to the electricity sector in Hong Kong and Thailand on a one day lag. This indicates that a partial driver of the electricity markets in each of these countries is the energy sector. Reverse Granger causality applies in the Philippines (on a one day lag) thus indicating that the electricity sector is the leading indicator of the energy sector of the stock market.

In each of the Hong Kong, the Philippines markets evidence is produced that when the electricity market is shocked by one standard deviation the energy market commences its move to stability one day after the shock and attains stability some three days after the shock. In the Thailand markets the move to stability of the energy sector commences one day after the shock but stability is still not achieved up to ten days after the shock. There is no evidence of cointegration in Chinese markets or in Malaysian markets thus indicating, when lagged data are considered, an electricity market that has decoupled from the energy market due to stronger forces of government interference in electricity pricing or that the process of liberalisation has not advanced due to lagging micro and micro economic reforms in the electricity sector.

The results of Granger causality tests are unclear in terms of the exogeneity of the energy market sectors. Further testing is needed so the error correction terms of the VECMs are revisited for further analysis. Table 5 shows the error correction terms for the country bivariate VECMs where there is evidence of cointegration on a lag order of one-two days. The error correction terms show the speed of each variable in the bivariate model towards equilibrium in the model. Absolute values are considered as a negative term indicates that the variable moves to stability from above equilibrium and the positive sign indicates the move to stability from below equilibrium.

The greater the magnitude of any statistically significant error correction term, the greater the speed towards stability of the model thus confirming exogeneity and the strength of the degree of liberalisation of the particular electricity markets (That is, the strength of the relationship between electricity and energy stock market sectors and thus the strength of the relationship between electricity markets and global fossil fuel prices). The $t$ statistics in excess of 1.75 in absolute terms are considered significant at the $10 \%$ level. The $t$ statistics are in parenthesis. In the various country-bivariate models it is expected that the energy sector (reflecting global fossil fuel prices) will be the exogenous force as the driver of the electricity market prices. When error correction terms are considered, the US and Indian markets exhibit reverse causality, where the electricity markets drive their energy markets.

Table 5. Error correction terms

\begin{tabular}{lllll}
\hline Country & $\begin{array}{l}\text { First differences: } \\
\text { Electricity prices } \\
\text { treated endogenously }\end{array}$ & $\begin{array}{l}\text { First differences: Energy } \\
\text { sector prices treated } \\
\text { endogenously }\end{array}$ & $\begin{array}{l}\text { Ranking of } \\
\text { magnitude of } \\
\text { significant error } \\
\text { correction terms }\end{array}$ & Exogenous variable \\
\hline US & $-0.0065(-2.4577)^{* *}$ & $-0.0012(-0.7229)$ & 6 & US electricity market \\
\hline UK & $-0.0014(-0.4929)$ & $0.0209(3.5414)^{*}$ & 1 & UK energy market \\
\hline The EMU & $-0.0006(-0.2743)$ & $0.0078(2.2283)^{* *}$ & 7 & The EMU energy \\
market
\end{tabular}

Note: Significance levels are at $10 \% *, 5 \% * *$ and $1 \% *$

Table 5 shows that the models behave as expected in terms of exogeneity of energy market sectors (where energy stock markets, and therefore fossil fuel prices are the drivers of the electricity markets), except in the cases of the larger electricity markets of the US and India. It may well be that this is because these latter electricity markets are so large that they are partial drivers of global fossil fuel prices. 
Nevertheless, in all of these cases it is posited that the strong relationship between electricity and energy markets represents progress in deregulation of the markets away from the control by private or public monopolies and government electricity pricing interference. If the speed towards equilibrium is reflected in the magnitude of the error correction term and that term is also an indicator of the degree of liberalisation of the electricity market (the degree of reliance on global fossil fuel prices) it might be said that the greater degree of deregulation is reflected in the rankings from 1 to 8 as follows: UK, India, Thailand, Hong Kong, the Philippines, the US, the EMU and New Zealand in that order.

\section{Discussion}

Support is provided for the work of Bosco et al (2006), Asche et al (2006), Mjelde and Bessler (2009), Mohammadi (2009), He, Zhang, Yang, Wang and Wang (2010), Mautinho, Vieira, and Moreira (2011), Ferkingstad, Lolan and Wilhelmsen (2011) and Furio and Chulia (2012). All of these researchers discovered long-term cointegrating relationships with fossil fuels. In summary, Bosco et al finds long-term equilibrium of electricity with oil prices in Europe; Asche with oil and gas in the UK; Mjelde and Bessler and Mohammadi with fossil fuels; He, Zhang, Yang, Wang and Wang with coal; Mautinho, Vieira, and Moreira in Spain with energy commodities; Ferkingstad, Lolan and Wilhelmsen in Nordic, German and UK electricity markets with gas and Furio and Chulia again in Spain examined electricity futures and futures markets in Brent oil crude and Zeebrugge gas and find cointegration with exogeneity lying with the fossil fuels.

The results in this study differ from those in the contemporaneous model developed by Simpson et al (2012). In the latter study the results imply significant unlagged relationships in each of the countries sampled between electricity and energy stock markets, thus implying differing degrees of electricity market liberalisation. The unlagged model shows that the larger economies whether developed or developing countries (EMU, China, US, India, UK) demonstrated stronger relationships thereby indicating greater electricity market liberalisation. In some economies such as New Zealand and Argentina there was a heavy use of renewables and this, combined with domestic regulatory costs, reduced the strength of the relationship between electricity and the energy sector.

When optimal lags are introduced (on the assumption that the markets in each country in reality do not react to each other contemporaneously), and a VECM is tested, many of the previously significant unlagged relationships in the Simpson et al (2012) study disappear. Cointegrating relationships are found in the OECD in all countries studied except Canada (where it is expected in future research that the US and the Canadian markets would be found to be closely related). Cointegrating relationships are not found in Latin America. In Asia cointegrating relationships are found in Hong Kong, India, the Philippines and Thailand, but not in China and Malaysia.

There is some support for exogeneity lying with the energy stock market sector on lags of one to two days in the various countries where cointegration is evident, but the results of the Granger causality tests are unclear. Re-examination of the error correction terms in the VECM on a lag order of 1-2 days confirms that in the US and India exogeneity lies with electricity sector. This implies that in those countries, because of the size of their markets and their influence on global fossil fuel prices, that it is the electricity market that is the leading indicator and not energy market sectors. In all of the other cointegrated markets (UK, the EMU, New Zealand, Hong Kong, The Philippines and Thailand) exogeneity as expected, lies with the energy market sector. In the cointegrated markets where there is evidence of Granger causality, impulse response functions confirm that when a shock is delivered to the electricity markets the path to stability of the models commence on a lag of 1 to 3 days and equilibrium is achieved quite rapidly within 3 to 7 days except in the case of Thailand where equilibrium is still not achieved after 10 days.

With respect to the error correction terms these indicate the speed of adjustment in each model and the speed explains how far advanced the countries are in terms of their deregulation. Higher speeds of adjustment mean greater degrees of deregulation than countries with a lower speed of adjustment. Speed of adjustment also explains how efficient the market is in terms of information adjustment speed between markets. A faster speed of adjustment means greater market efficiency.

\section{Limitations}

Electricity is not a commodity where the law of one price will hold across borders. This paper makes the broad assumption, however, that if electricity prices are quoted for a country the implication is that there is a single electricity market in that country. Moreover, different countries have differing energy for electricity generation. The limitation of this study is that it cannot fully compare an energy stock market sector price, which is based on global fossil fuel prices, to prices of sources of energy for electricity based mainly in nuclear or renewables. It must assume that the main drivers of electricity prices in an open market are the prices of fossil fuels, but in reality for many countries this is unlikely to be the case. There are also different technologies in different 
countries which may render markets in some countries inefficient in terms of costs of electricity production. Future research might take into account differences between countries in the relationships due to seasonality in Northern and Southern hemispheres. These limitations make the paper theoretical with some empirical evidence that affords it limited applicability to models of electricity and energy market pricing.

\section{Conclusion}

In this study, where lags are introduced in a VECM specification for a representative sample of OECD, Latin American and Asia economies, the most liberalised electricity markets (according to the strength of the indirect connection with global fossil fuels with the energy stock market sector through evidence of cointegration), are the OECD countries of the US, the UK, the EMU, and New Zealand and the Asian countries in Hong Kong, India, the Philippines and Thailand. In these countries, it is posited, that there is less influence on the electricity prices of regulatory costs than in for example, the Latin American countries, China and Malaysia where there is no evidence of cointegration. A continuing nexus between electricity prices and energy sectors has market liberalisation implications as well as environmental implications, because of the continuing dependence on fossil fuels.

Where cointegration evidence is found it suggests that, whilst electricity and energy prices might behave differently in the short-term due to different degrees of market regulation, the prices converge in the long-run with energy sectors reacting directly to the market interaction of global fossil fuel supply and demand conditions. It is posited that this long-term relationship represents rational expectations and a greater degree of electricity market liberalisation (less interference in electricity pricing through private or public electricity monopolies than in those countries where cointegration is not evident).

As mentioned, there is no evidence of strong liberalisation and deregulation of the Latin American electricity markets based on cointegration and exogeneity testing. Some of the countries in the sample have a strong dependence on renewables (For example, Argentina), but it is put that this only means greater electricity market liberalisation if there is minimal government interference in pricing. As mentioned, in some countries where the markets are cointegrated there is no evidence of Granger causality. As an alternative to Granger exogeneity tests the study considered the magnitude and significance of the error correction terms from a VECM on a lag order of 1-2 days. This confirms exogeneity of electricity markets in the US and India perhaps because of their size and their influence of their markets on global fossil fuel prices.

In the cases of New Zealand, the EMU, the UK, Hong Kong, the Philippines and Thailand when error correction terms are considered, exogeneity lies with the energy sectors as expected. Additional evidence of causality and equilibrium relationships is provided in impulse response functions, which are considered only for those countries where there is Granger causality evidence. That is, for the US, the UK, Hong Kong, The Philippines and Thailand. Impulse response functions verify that the path towards equilibrium in those countries commences in 1-3 days and that equilibrium (except in the case of Thailand) is achieved after 3-7 days.

It is demonstrated in this study that lagged bivariate models of electricity and energy stock market sectors, in their relaxation of the assumption of contemporaneous adjustment, can better explain the extent of country and perhaps regional electricity market liberalisation. More research is needed to apply the lagged model to a greater range of countries where electricity prices are reported daily together with energy stock market sectors and when more is known about the costs of nuclear and renewables power generation.

\section{References}

Andrews, D. W. K. (1993). Tests for Parameter Instability with Unknown Change Points. Econometrica, 61(4), 821-856.

Asche, F., Osmundsen, P., \& Sandsmark, M. (2006). The UK Market for Natural Gas, Oil and Electricity: Are the Prices Decoupled? The Energy Journal, 27(2), 27-40.

Bosco, B., Parisiol, L., \& Pelegatti, M. (2006). Deregulated Wholesale Electricity Prices in Europe. University Degli Studi di Milano-Bicocca, Department of Statistics, Working Paper Series, N20061001.

Ferkingstad, E., Lolan, A., \& Wilhelmsen, M. (2011). Causal Modeling and Inference for Electricity Markets. Energy Economics, 33, 404-412. http://dx.doi.org/10.1016/j.eneco.2010.10.006

Furio, D., \& Chulia, H. (2012). Price and Volatility Dynamics between Electricity and Fuel Costs: Some Evidence for Spain. Energy Economics, http://dx.doi.org/10.1016/j.enerco.2012.02.014

Granger, C. W. J. (1988). Some Recent Developments in a Concept of Causality. Journal of Econometrics, 39, 199-211. http://dx.doi.org/10.1016/0304-4076(88)90045-0 
He, Y. X., Zhang, S. L., Yang, L. Y., Wang, Y. J., \& Wang, J. (2010). Economic Analysis of Coal Price-Electricity Price Adjustment in China Based on the CGE Model. Energy Policy, 38, 6629-6637. http://dx.doi.org/10.1016/j.enpol.2010.06.033

Johansen, S. (1988). Statistical Analysis of Cointegration Vectors. Journal of Economic Dynamics and Control, 12, 231-254. http://dx.doi.org/10.1016/0165-1889(88)90041-3

Mautinho, V., Vieira, J., \& Moreira, A. C. (2011). The Crucial Relationship among Energy Commodity Prices: Evidence from the Spanish Electricity Market. Energy Policy, 39, 5898-5908. http://dx.doi.org/10.1016/j.enpol.2011.06.043

Mjelde, J. W., \& Bessler, D. A. (2009). Market Integration among Electricity Markets and their Major Fuel Source Markets. Energy Economics, 31, 482-491. http://dx.doi.org/10.1016/j.eneco.2009.02.002

Mohammadi, H. (2009). Electricity Prices and Fuel Costs: Long-Run Relations and Short-Run Dynamics. Energy Economics, 31, 503-509. http://dx.doi.org/10.1016/j.eneco.2009.02.001

Phillips, P. C. B., \& Perron, P. (1988). Testing for a Unit Root in a Times Series Regression. Biometrika, 75, 335-346. http://dx.doi.org/10.1093/biomet/75.2.335

Quandt, R. E. (1988). The Econometrics of Disequilibrium. Oxford, Blackwell Press.

Simpson, J. L., Buyukkara, G., \& Mon Abraham, S. (2012). A Contemporaneous Model of Electricity Market Interaction with Energy Stock Market Sectors. The Electricity Journal, 25(6), July.

\section{Appendix 1: Impulse Response Functions for countries with long-term equilibrium relationships}

Note: In each case, the interest lies in the response of the energy sector to a one standard deviation shock (See Cholesky one S.D Innovation) to the electricity sector in price changes. The response of the energy sector mainly indicates that the optimal lag is the point of commencement of the movement of the exogenous variable towards equilibrium or stability. Number of periods in days is on the horizontal axis in each case.

The main graphs to peruse are therefore on the bottom left panel for each country. E.g. Response of Oilgsus to Elctus; Response of Oilgsuk to Electuk Etc.

$\underline{\mathbf{U S}}$

Response to Cholesky One S.D. Innovations
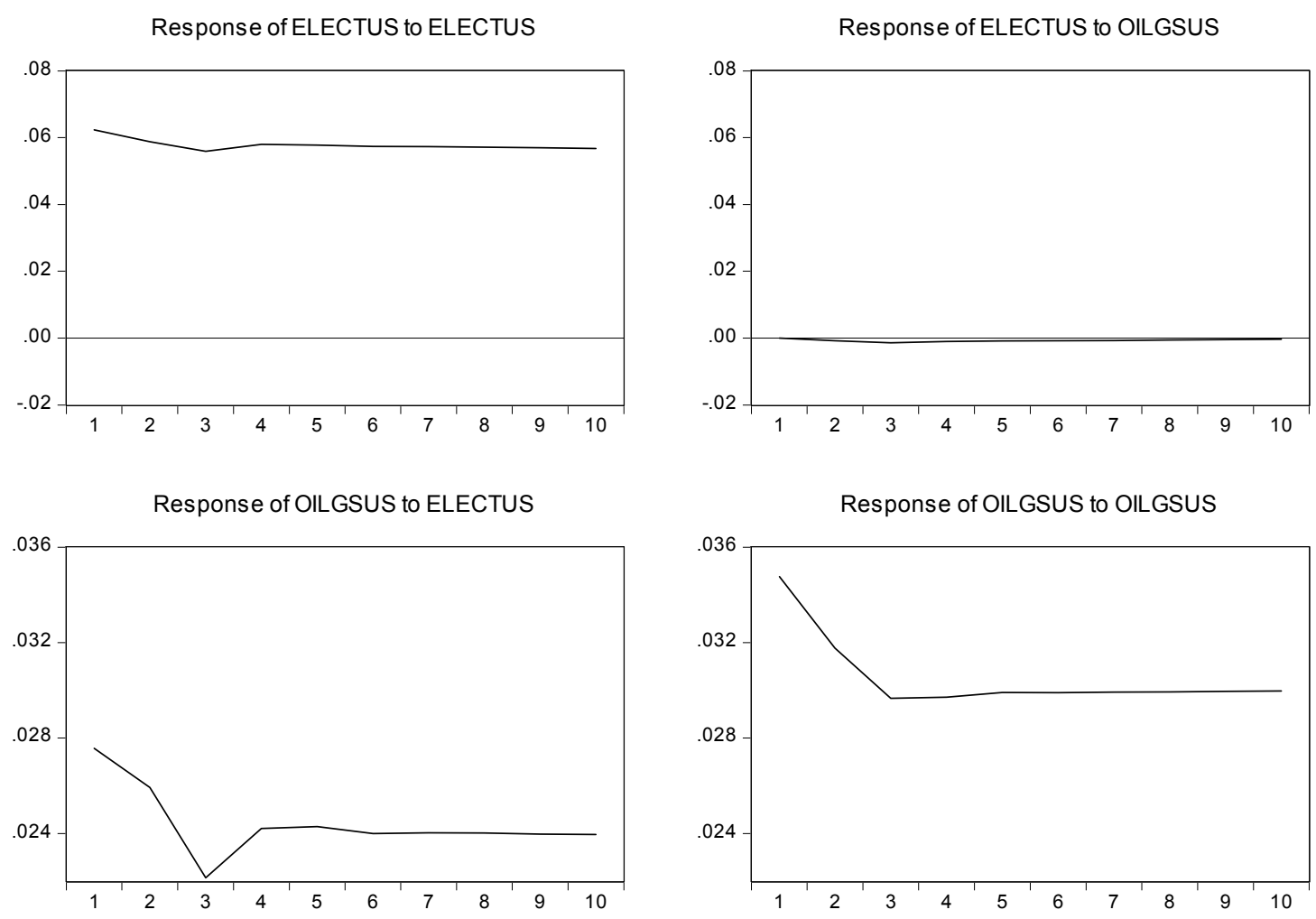


\section{UK}

Response to Cholesky One S.D. Innovations

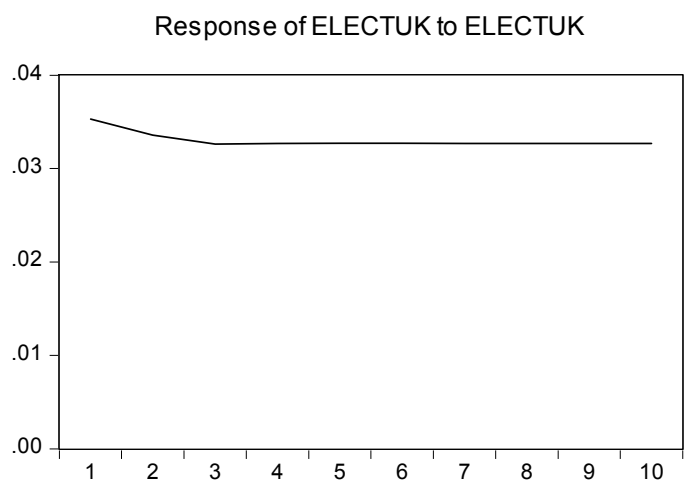

Response of ELECTUK to OILGSUK

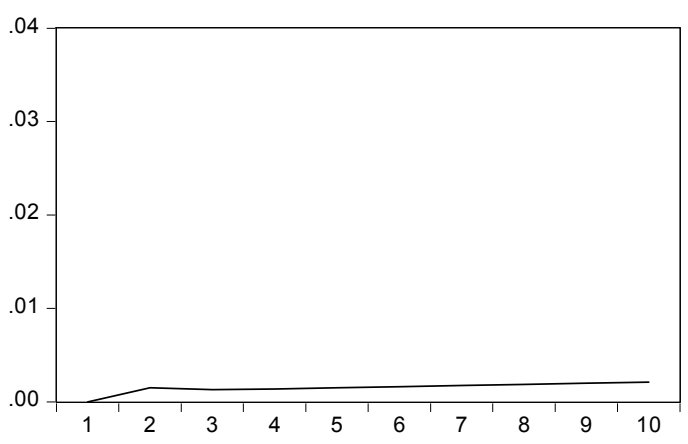

Response of OILGSUK to ELECTUK

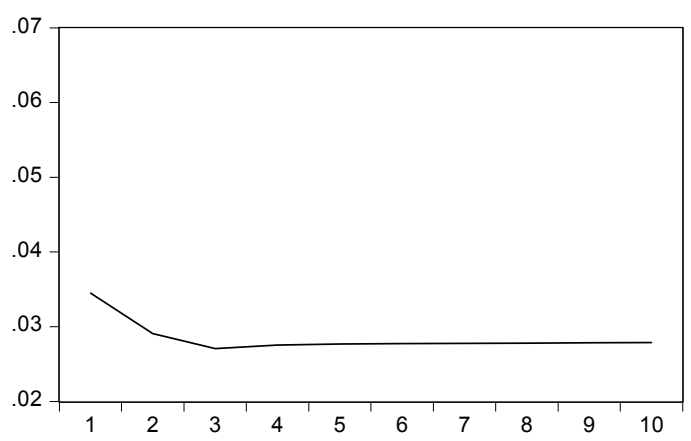

Response of OILGSUK to OILGSUK

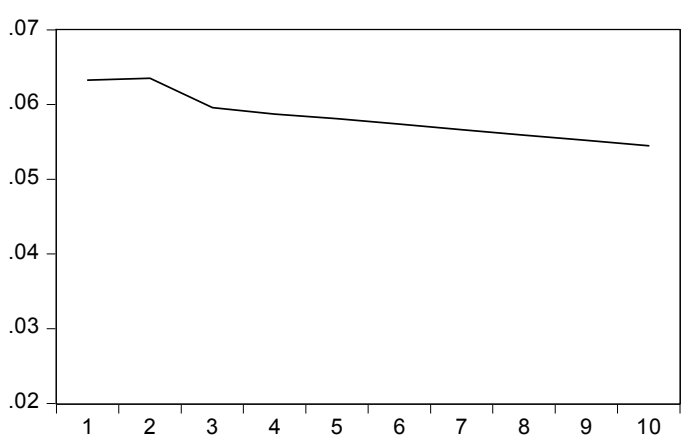

\section{Hong Kong}

\section{Response to Cholesky One S.D. Innovations}
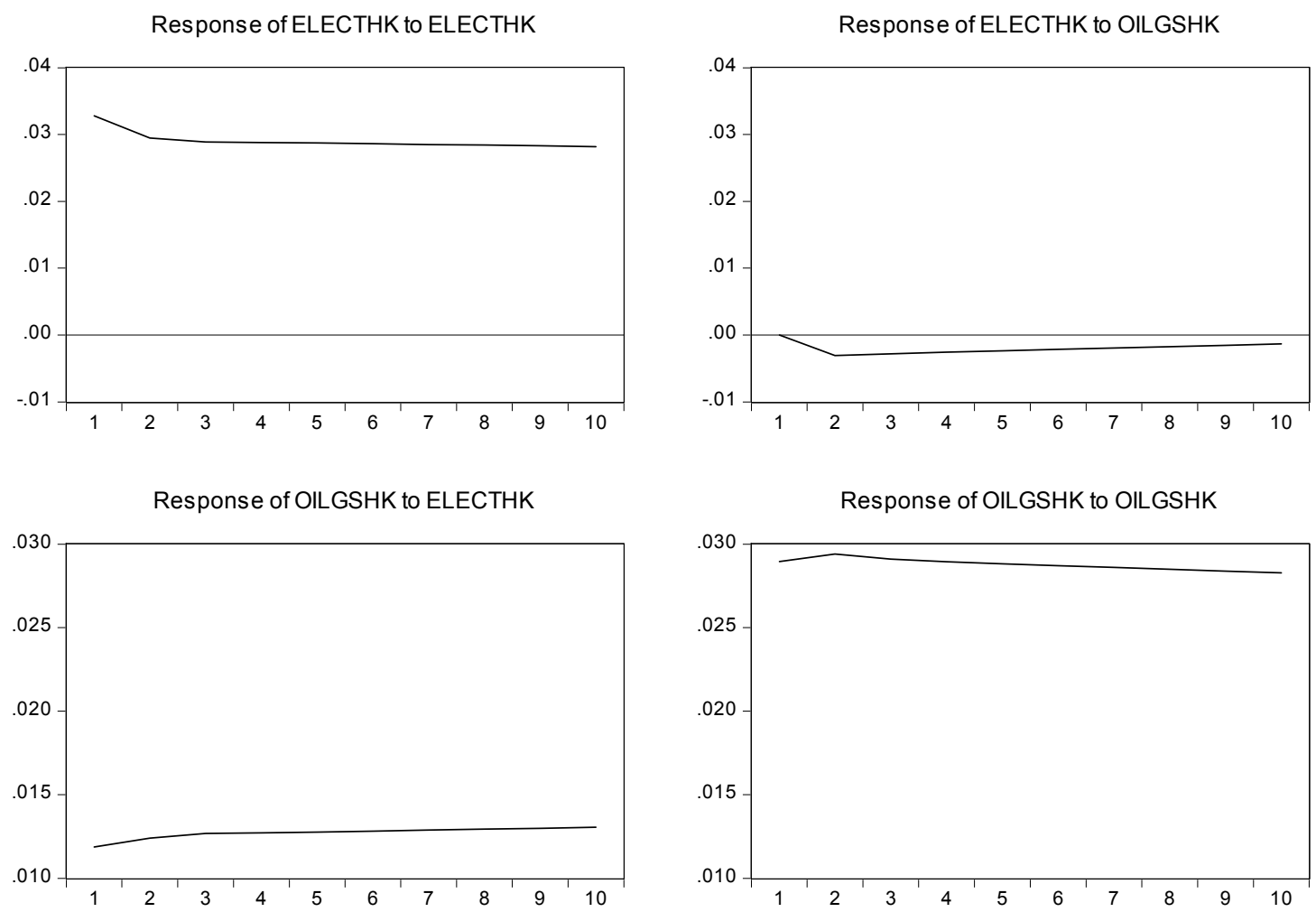


\section{The Philippines}

Response to Cholesky One S.D. Innovations

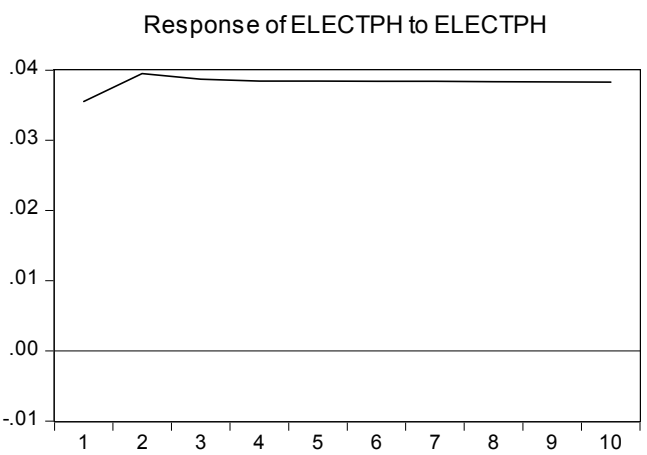

Response of ELECTPH to OILGSPH

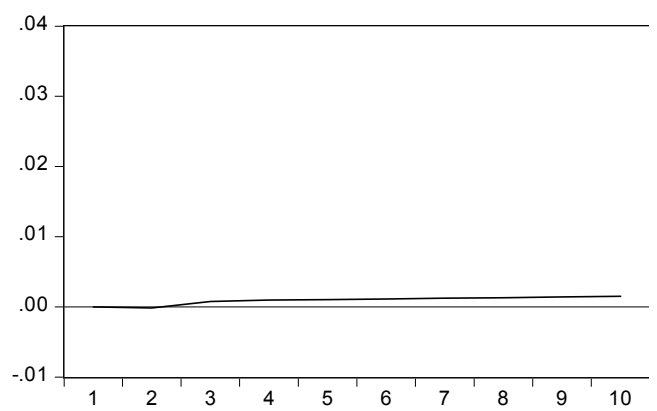

Response of OILGSPH to ELECTPH

Response of OILGSPH to OILGSPH
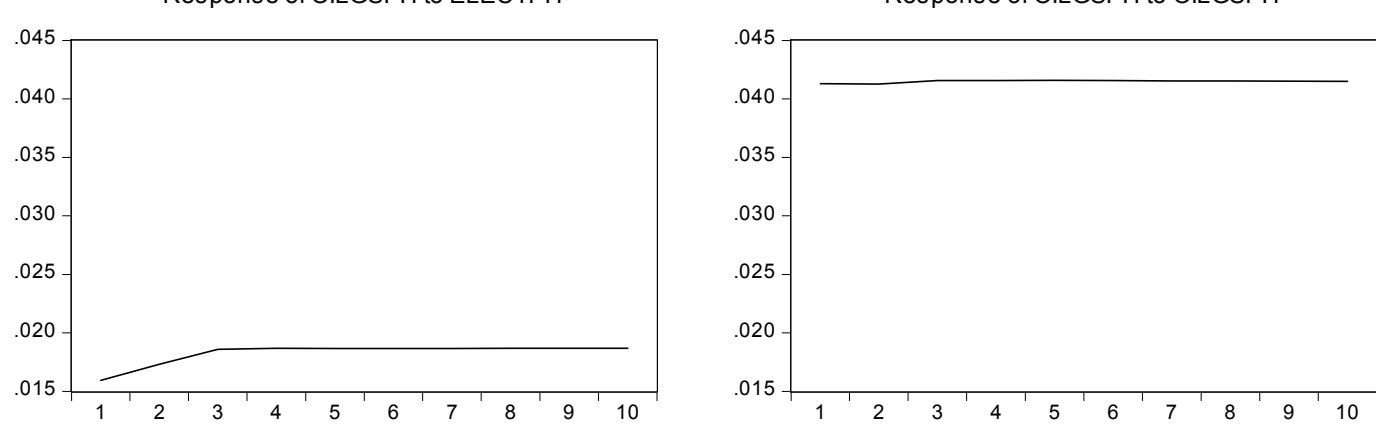

\section{Thailand}

Response to Cholesky One S.D. Innovations

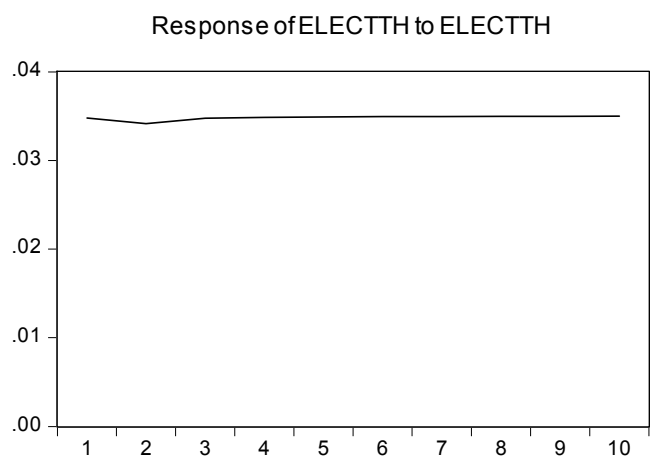

Response of ELECTTH to OILGSTH

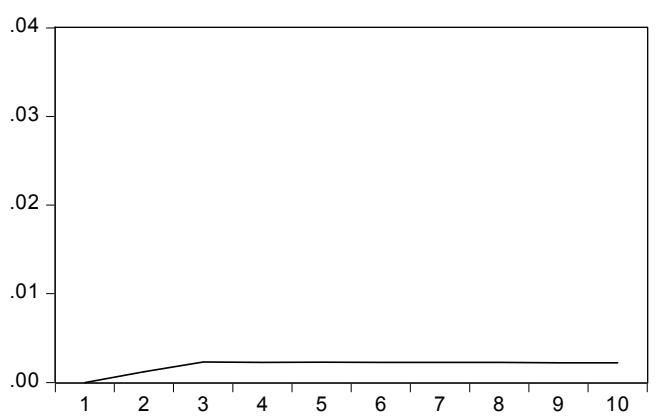

Response of OILGSTH to ELECTTH

Response of OILGSTH to OILGSTH
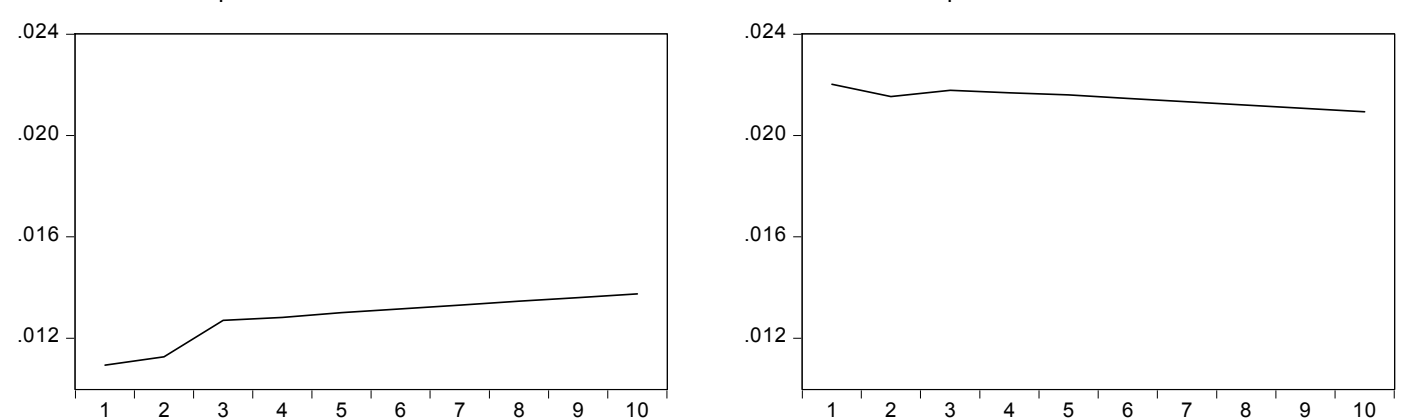